Community Care for Older People 


\section{Also by Susan Tester}

Cash and Care: The Relations between

Supplementary Benefit and Other Agencies

Social Loans in the Netherlands

III-Informed? A Study of Information and Support for

Elderly People in the Inner City (with Barbara Meredith)

Caring by Day: A Study of Day Care Services for Older People

Common Knowledge: A Co-ordinated Approach to Information-Giving 


\title{
Community Care for Older People
}

A Comparative Perspective

\author{
Susan Tester
}

Lecturer in Social Policy, University of Stirling

Consultant Editor: Jo Campling

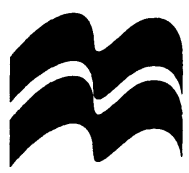


First published in Great Britain 1996 by

MACMILLAN PRESS LTD

Houndmills, Basingstoke, Hampshire RG21 6XS

and London

Companies and representatives

throughout the world

A catalogue record for this book is available

from the British Library.

ISBN 978-0-333-54934-6

ISBN 978-1-349-24479-9 (eBook)

DOI 10.1007/978-1-349-24479-9

First published in the United States of America 1996 by

ST. MARTIN'S PRESS, INC.,

Scholarly and Reference Division,

175 Fifth Avenue,

New York, N.Y. 10010

ISBN 978-0-312-15912-2

Library of Congress Cataloging-in-Publication Data applied for

C Susan Tester 1996

All rights reserved. No reproduction, copy or transmission of this publication may be made without written permission.

No paragraph of this publication may be reproduced, copied or transmitted save with written permission or in accordance with the provisions of the Copyright, Designs and Patents Act 1988, or under the terms of any licence permitting limited copying issued by the Copyright Licensing Agency, 90 Tottenham Court Road, London WIP 9HE.

Any person who does any unauthorised act in relation to this publication may be liable to criminal prosecution and civil claims for damages.

$\begin{array}{llllllllll}10 & 9 & 8 & 7 & 6 & 5 & 4 & 3 & 2 & 1\end{array}$

$\begin{array}{llllllllll}05 & 04 & 03 & 02 & 01 & 00 & 99 & 98 & 97 & 96\end{array}$

Copy-edited and typeset by Povey-Edmondson

Okehampton and Rochdale, England 
For Charlie and Nathalie 


\section{Contents}

List of Tables

viii

Acknowledgements

ix

List of Abbreviations

$\mathrm{X}$

1 Introduction 1

2 Financing of Services and Benefits 26

3 Accommodation for Older People 53

4 Domiciliary Care $\quad 76$

5 Health Services Outside the Home 102

6 Day Care, Leisure and Education 126

7 Coordination of Community Care Services 147

8 Summary and Conclusions $\quad 171$

$\begin{array}{lr}\text { References } & 189\end{array}$

$\begin{array}{ll}\text { Index } & 202\end{array}$ 


\section{List of Tables}

1.1 Proportions of older people in populations of countries studied, 1990

1.2 Public expenditure on social protection as a percentage of GDP

1.3 Framework for analysis of origins, substance and outcomes of community care

2.1 Total expenditure on health as a percentage of GDP

2.2 Projected increase in ratio of over 65 age group to 15-64 age group, 1990-2025

2.3 Projected increase in percentage of over $65 \mathrm{~s}$ in populations, 1990-2025

2.4 Public expenditure on social protection for old age as a percentage of GDP, 1990

2.5 Benefits from social insurance and social assistance 47

3.1 Proportion of over 65 age group living alone 64

3.2 Places in residential and nursing home care per 100 people aged 65 and over

4.1 Domiciliary care needs and services 84

4.2 Life expectancy at birth for men and women, $1989 \quad 84$

4.3 Percentage of women in older age groups, $1989 \quad 85$

4.4 Percentage of population aged $65+$ receiving home care 94

5.1 Health care needs and services outside the home 109

5.2 Public expenditure on health as a percentage of total health expenditure, 1970-1990

5.3 Numbers of inpatient hospital beds per 1000 population, and average lengths of stay in inpatient care, 1970-1990

5.4 Total expenditure on ambulatory care as a percentage of total expenditure on health, 1970-1990

6.1 Percentage of older people aged $60+$ in the labour force, 1983-1991

6.2 Frequency of contacts with family for people aged $60+$, 1992

6.3 Social and leisure needs and services

7.1 Coordination arrangements and procedures 


\section{Acknowledgements}

Many people have contributed to this study in various ways during the past few years. I am grateful for all their help, even though it is not possible to name them all here. Financial support for study visits was provided by the Council of Europe, the Marjory Warren Funds and the University of Stirling Research Fund. Thanks are due to all those who helped me to organise my study visits to France, Germany, the Netherlands and the United States of America. Ulla Rydberg gave much help and companionship at the University of Florida; her untimely death was a great sadness. I am most grateful to all the policymakers, professionals, care workers and service users in the institutes and agencies visited, who gave their time to answer my questions and explain policies and practice to me.

My task of producing the book was assisted by the helpful comments of those who read draft chapters, including George Giarchi, Christine Hallett, Hannelore Jani, Barbara Klein, Otto von Mering, Robert Pinker, Willi Rückert and, especially, Barbara Meredith and Henk Nies who provided detailed comments on all chapters. Christopher Turner gave support and encouragement through the long process of writing. Sue Dyer helped with preparation of the typescript. I am grateful to my editor, Jo Campling, for suggesting the book and for her patience in awaiting its completion. Thanks are also due to Frances Arnold and Catherine Gray at the publishers and to the anonymous reader for helpful comments on the first draft. I appreciate all the help received from all those involved; responsibility for the accuracy of the contents, however, remains my own.

Susan Tester 


\section{List of Abbreviations}

AAA Area Agency on Aging (US)

AARP American Association of Retired Persons (US)

ACE Age Concern England (UK)

ADL Activities of Daily Living

AMA Association of Metropolitan Authorities (UK)

AoA Administration on Aging (US)

AWBZ Algemene Wet Bijzondere Ziektekosten (Exceptional Medical Expenses Act, Netherlands)

BMFuS Bundesministerium für Familie und Senioren (Federal ministry for families and older people, Germany)

CCAS Centre Communal d'Action Sociale (municipal social services centre, France)

CEC Commission of the European Communities

DHHS Department of Health and Human Services (US)

DHSS Department of Health and Social Security (UK)

EC European Community

EU European Union

FRG Federal Republic of Germany

GDP Gross Domestic Product

GDR German Democratic Republic

GHS General Household Survey (UK)

GP General practitioner

HMO Health Maintenance Organisation (US)

HMSO Her Majesty's Stationery Office (UK)

KDA Kuratorium Deutsche Altershilfe (Germany)

NHS National Health Service (UK)

NISW National Institute for Social Work (UK)

OAA Older Americans Act (US)

OECD Organisation for Economic Cooperation and Development

OPCS Office for Population Censuses and Surveys (UK)

PSSRU Personal Social Services Research Unit (UK)

RADAR Royal Association for Disability and Rehabilitation (UK) 
RIAGG Regionale Instelling voor Ambulante Geestelijke Gezondheidszorg (Regional institute for outpatient mental health services) (Netherlands)

SSI Social Services Inspectorate (UK)

SSN Servizio Sanitario Nazionale (National Health Service, Italy)

SUA State Unit on Aging (US)

SWSG Social Work Services Group (UK)

UK United Kingdom

US United States

USL Unità Sanitarie Locali (local health units, Italy)

VA Veterans Administration (US) 